in excess of that used in the other experiments discussed here.

$$
\text { D. S. HART }
$$

Canterbury Agricultural College,

Christchurch, New Zealand,

J. W. BenNetT

J. C. D. HuTChinson

MaNiKa Wodzicka-ToMaszewsKa*

C.S.I.R.O. Division of Animal Physiology,

Ian Clunies Ross Animal

Research Laboratory,

Prospect, New South Wales,

Australia.

* Present address: Whatawhata Hill Country Research Station, Hamilton, New Zealand.

1 Morris, L. R., Nature, 190, 102 (1961).

${ }^{2}$ Bennett, J. W., Hutchinson, J. C. D., and Wodzicka-Tomaszewska, Manika, Nature, 194, 651 (1962)

Hart, D. S., J. Agric. Sci., 56, 235 (1961) - Ferguson, K. A., Carter, H. B., and Hardy, Margaret H., Austral. J. Sci.

${ }^{s}$ Wildman, A. B., Bull. Wool. Indust. Res. Assoc., 24, 38 (1962).

- Symington, R. B.. Nature, 184, 1076 (1959).

\section{Consumption of Oxygen by Sweat Glands of Indian Zebu Cattle}

OXYGEN consumption of skin slices is correlated with the volume of sweat glands and is increased after injection of pilocarpine $\theta^{1,2}$. The metabolism of glucose and glycolysis has been studied in the skin slices ${ }^{3,4}$. There is a greater evaporation of sweat from the hump of the Indian zebu cattle ${ }^{5,6}$

An attempt has been made to investigate the role of hump and dewlap of Indian zebu cattle in thermoregulation by examining the oxygen consumption of skin slices, containing intact sweat glands in large numbers, both as whole skin thickness and as papillary layer, in a Warburg respirometer. Samples were procured by biopsy after intradermal anæsthesia with 2 per cent solution of procaine from adult Hariana breeds of zebu cattle. Papillary layer was separated by stretching and free-hand sections of $150-250 \mu$ thickness were cut parallel to the direction of the hair follicles from three regions of hump, dewlap and dorsal trunk. Oxygen consumption was measured in $3 \mathrm{ml}$. Krebs-Ringer phosphate buffer at $p \mathrm{H} 7 \cdot 4$ substrate and in presence of $0.5 \mathrm{M}$ sodium succinate and $0.114 \mathrm{M}$ sodium ascorbate ${ }^{7}$ to study the comparative role of flavoprotein systems and cytochrome oxidase in the respiration of skin, and the excess oxygen intake over that of substrate has been shown in Table 1. Oxygen consumption increased with succinate and ascorbate substrates markedly. Table 2 shows the oxygen consumption of papillary layer with ascorbate substrate and its possible correlation with the sweating-rate index, density of sweat glands, sweat gland volume and the product of the last two figures. There is a definite correlation between oxygen consumption, sweating rate and the product of density and volume of sweat glands, although the product value is slightly, but insignificantly higher in dewlap than in the dorsal trunk. It is concluded that hump is well developed as an evaporative surface for thermoregulation in Indian zebu cattle.

Table 1. Nxygen consumption in $\mu \mathrm{l} . / \mathrm{mg}$ dry weight of skin slices of Indian breed of Hariana bulls of the whole skin thickness and papillary layer from the three regions of hump, dewlap and dorsal trunk in Krebs-Ringer phosphate buffer, $p \mathrm{H} 7 \cdot 4$, without substrate (WS) and excess oxygen intake over (ASC) substrates. Gas phase, 100 per cent oxygen. Average of 15 experi(ASC) substrates. Gas phase, 100 per cent oxygen. Average of 15 experiments \pm standard deviation and percentage increase of oxygen
with substrates over that of $W S$ is shown in parentheses

\begin{tabular}{|c|c|c|c|c|c|c|}
\hline Region & 48 & Whole skin & $\mathrm{SO}$ & W & illary la & $3 \mathrm{C}$ \\
\hline Hump & $0.6 \pm 0.05$ & $0.3 \pm$ & 08 & $0.9 \pm 0.08$ & $1.5 \pm 0.07$ & 0.07 \\
\hline ewlap & 0.08 & $0.1 \pm 0.03$ & $1.8 \pm 0.05$ & $0.8 \pm 0.05$ & $0.6 \pm 0.05$ & $2 \pm 0.04$ \\
\hline $\begin{array}{r}\text { Dorsal } \\
\text { trunk }\end{array}$ & $0.6 \pm 0.05$ & $\begin{array}{c}0.2 \pm 0.03 \\
(33)\end{array}$ & $\begin{array}{c}2 \cdot 8 \pm 0 \cdot 06 \\
(470)\end{array}$ & $0.9 \pm 0.05$ & $\begin{array}{c}1.0 \pm 0.07 \\
(110)\end{array}$ & $\begin{array}{c}4 \cdot 5 \pm 0.06 \\
(500)\end{array}$ \\
\hline
\end{tabular}

Table 2. Relation between density of sweat gland/sq. cm. of skin, sweat gland volume $\left(\mu^{3} \times 10^{6}\right)$, sweating rate index as reciprocal of time in minutes $\times 100$ required for cobalt anhydride paper disks to change colour product of density and volume $\times 10^{-4}$, and oxygen consumption in $\mu \mathrm{l} . / \mathrm{mg}$ dry weight of papillary layer of skin slices with ascorbate substrat $\mu 1 . /$ ing dry weight or papillary layer of skin slices with ar

$\begin{array}{lccccc}\text { Region } & \text { Density } & \text { Volume } & \begin{array}{c}\text { Density vol. } \\ \text { product }\end{array} & \begin{array}{c}\text { Sweating } \\ \text { rate index }\end{array} & \begin{array}{c}\text { Oxygen } \\ \text { consumption }\end{array} \\ \text { Hump } & \mathbf{1}, 720 \pm 61 & 21 \cdot 7 \pm 3 \cdot 1 & 37 \cdot 3 & \mathbf{4 5} \pm \mathbf{4} \cdot 5 & \mathbf{5} \cdot 6 \pm 0 \cdot 07 \\ \text { Dewlap } & 1,614 \pm 91 & 16 \cdot 5 \pm 2 \cdot 9 & 26 \cdot 6 & 17 \pm 2 \cdot 6 & 3 \cdot 2 \pm 0 \cdot 04 \\ \text { Dorsal } & 1,388 \pm 108 & 17 \cdot 4 \pm 2 \cdot 5 & \mathbf{2 4} \cdot \mathbf{6} & \mathbf{3 1} \pm \mathbf{3} \cdot 3 & 4 \cdot 5 \pm 0 \cdot 06 \\ \text { trunk } & & & & & \end{array}$

We are indebted to I.C.A.R. for grants-in-aid to defray the expenses of the investigation and to Principal M. S. Das for facilities.

$$
\begin{aligned}
& \text { D. P. Sadhu* } \\
& \text { D. Roy Chowdhury } \dagger
\end{aligned}
$$

Department of Physiology and Nutrition, Bengal Veterinary College, Calcutta, 37.

* Present address: Postgraduate College of Animal Sciences, IVRI, Izatnagar, India.

$\dagger$ Present address: Department of Biochemistry, Nagpur University, Nagpur, India.

1 Medawar, P. B., Quart J. Micro. Sci., 89, 187 (1948).

${ }^{2}$ O'Hara, K., Jap. J. Physiol., 2, 1 (1951).

${ }^{3}$ Cruickshank, C. N. D., Exp. Cell Res., r, 374 (1954).

- Cruickshank, C. N. D., and Trotter, M. D., Biochem. J, 62, 1 (1956)

Kibler, H. H., and Yeck, R. G., Univ. Missouri Agric. Exp. Sta. Res. Bull. No. 701 (1959)

- Roy Chowdhury, D., and Sadhu, D. P., Nature, 189, 491 (1961).

Umbreit, W. W., Burris, R. H., and Stauffer, J. F., Manometric Techniques, 174 (Burgess Publishing Co., Minneapolis, 1957).

\section{Uterus and Occurrence of Estrus in Pigs}

THE persistence of functional corpora lutea following hysterectomy during the active luteal phase of the cestrous cycle in the gilt ${ }^{1}$, heifer ${ }^{2}$ and guinea pig $^{3,4}$ indicates a functional interdependence between the ovary and uterus. Sub-total hysterectomy (from posterior halves of oviducts to mid-cervix) was performed in 28 cycling gilts at various stages of the cestrous cycle, days $1,5,10$, 14,16 and 18. The first day of œstrus was designated day 1 of the cycle. Experimental procedures have already been described ${ }^{1}$. Corpora lutea were marked with sterile animal charcoal at hysterectomy. Ovulation occurred in each of gilts hysterectomized on day 1 and newly formed corpora lutea persisted 120 days (Table 1). Gilts hysterectomized during active luteal phase of cycle, days 5,10 and 14, did not return to cestrus for a period of 120 days after the cestrus prior to surgery. Functional appear. ing carbon-marked corpora lutea were present in each of the gilts in these 3 groups. Corpora lutea were maintained. at least 120 days in 3 of 5 gilts hysterectomized on day 16 of the cycle; two of these gilts each had one 20-day œstrous interval following surgery. Corpora lutea formed after this post-operative oestrus persisted 120 days. Three of 4 gilts hysterectomized on day 18 of the cycle returned to œstrus within 4 days. These 3 gilts did not show further signs of ostrus in the following 4 months. One gilt in this group did not show ostrous behaviour following hysterectomy; however, ovulation did occur. Carbonmarked corpora albicantia and unmarked corpora lutea were present in ovaries at slaughter in this gilt as well as the other 3 gilts hysterectomized on day 18.

Removal of the uterus during cestrual, day 1 , or active luteal phase, days 5, 10 and 14, of the cycle in this litter. bearing species results in maintenance of luteal tissue for a period equal to that of gestation. Furthermore, luteal tissue persists in the majority of gilts hysterectomized during late luteal phase, day 16. Hysterectomy in procestrual phase, day 18, is followed by ostrus and ovulation within a few days in the majority of gilts. Thus days 16-18 represent a period in which presence of luteo. lytic or absence of luteotrophic action alters the life-span of the corpora lutea of the cycle in this species. Luteolytic action at this time is not prevented by removing the 